Newfoundland and Labrador Studies

\title{
Heather Igloliorte, ed. SakKijâjuk: Art and Craft from Nunatsiavut
}

\section{Charlotte Jones}

Volume 33, numéro 2, 2018

URI : https://id.erudit.org/iderudit/1058082ar

DOI : https://doi.org/10.7202/1058082ar

Aller au sommaire du numéro

\section{Éditeur(s)}

Faculty of Arts, Memorial University

\section{ISSN}

1719-1726 (imprimé)

1715-1430 (numérique)

Découvrir la revue

Citer ce compte rendu

Jones, C. (2018). Compte rendu de [Heather Igloliorte, ed. SakKijâjuk: Art and Craft from Nunatsiavut]. Newfoundland and Labrador Studies, 33(2).

https://doi.org/10.7202/1058082ar d'utilisation que vous pouvez consulter en ligne.

https://apropos.erudit.org/fr/usagers/politique-dutilisation/ 
BOOK REVIEWS

Heather Igloliorte, ed. SakKijâjuk: Art and Craft from Nunatsiavut. Fredericton, NB: Goose Lane Editions, and St. John's: The Rooms Corporation of Newfoundland and Labrador, Provincial Art Gallery Division, 2017. ISBN 978-0-86492-974-7

SakKijâjuk: Art and Craft from Nunatsiavut was published as a catalogue to accompany the exhibition of the same name at The Rooms Provincial Art Gallery from October 2016 to January 2017 (currently on view at the Art Gallery of Nova Scotia and touring across the country). It includes the work of 47 Inuit artists from Labrador and spans roughly the period since Newfoundland and Labrador's Confederation with Canada in 1949 to the present. The exhibition and its catalogue are the work of Heather Igloliorte, a Labrador Inuk who is a curator and an Indigenous art historian at Concordia University. Exhibition and publication are divided into four sections: InutuKait/ Elders; AkKusiuttet/Trailblazers; Ikualattisijet/Fire Keepers; and Kingullet Kinguvâtsait/The Next Generation. Works include fine craft (jackets, boots, mitts, and basketry, for example) and drawings, paintings, original prints, textiles, photographs, and sculpture. Igloliorte wrote the introductory essay and invited four other writers to contribute essays for each section: Jenna Joyce Broomfield (Elders), Aimee Chaulk (Trailblazers), Christine Lalonde (Fire Keepers), and Barry Pottle (The Next Generation). Most of the works in the catalogue are beautifully photographed by St. John's artist, Ned Pratt.

SakKijâjuk translates from the Labrador dialect of Inuktitut as "to be invisible"; thus, Igloliorte's introductory essay examines how it came to be that Labrador Inuit art and artists were left out of the 
Inuit art "boom" that began in the 1950s and how this omission impacted the artwork and the economy of Nunatsiavummuit artists and craftspersons. Igloliorte explains that when Newfoundland and Labrador joined Canada in 1949, the Terms of Union made no mention of the Indigenous peoples of the province - the Inuit, Innu, Métis, and Mi'kmaq. The net result was that Labrador Inuit (along with the other Indigenous peoples) did not have access to federal programs such as the Inuit Art Foundation, which included initiatives to support the development and marketing of Inuit art and craft. This presented challenges for the arts and craft sector in Labrador, and involved difficulty in accessing materials and in pursuing arts education. It also stifled the ability of Inuit artists in Labrador to network and to access art markets.

Igloliorte notes that Labrador Inuit differ from Inuit elsewhere in the country in some significant respects. There have been over 400 years of sustained contact with Europeans. Particularly important is contact with the Moravians and the impact of their form of Christianity on the culture. Additionally, Nunatsiavummiut represent the most southerly population of Inuit worldwide. Their land spans the taiga and tundra, which support forests of aspen and spruce. In terms of Labrador Inuit arts and craft, that means that the Inuit in the region could use wood as a material for their artwork.

In the first section, Elders, the earliest work - printed slide transparencies by James Anderson - dates to the 1950s but other work by Elders, for example, the beaded sealskin boots by Andrea Flowers, were created recently. Standout works in this section are Chesley Flowers's magnificent caribou herd, 46 wood and caribou antler carvings, and Doris Saunders's exquisite embroideries.

The next section, Trailblazers, discusses and demonstrates the work of the second generation of Labrador Inuit artists. Unlike Inuit elsewhere in Canada where government programs established print and carving workshops and provided on-location training and education, this group of artists had to leave Labrador if they wanted arts training. The works by the 11 artists — whether the artist left Labrador 
or not - are innovative and sophisticated, and many challenge the concept of what is "authentic" Inuit art. Maria Merkuratsuk uses a traditional pattern for her sealskin mitts but the mitts are a brilliant red. Michael Massie was educated at the Nova Scotia College of Art and Design. His superb Boa-Tea (1996) is an elegant sculpture/teapot fabricated with a jeweller's skill from silver, tulipwood, and ivory. Likewise, Shirley Moorhouse and Dinah Andersen both travelled to Ottawa for their education. Moorhouse's painterly wall hangings, which use found objects along with caribou hide and beadwork, reflect on her place, her people's stories, and scientific and environmental narratives.

Fire Keepers, the third section, includes such diverse work as the digitally manipulated photographs of Michelle Baikie; paintings by Mark Igloliorte and Heather Campbell, both of whom tackle environmental and northern experience in a fresh and contemporary manner; the sculptures of Billy Gauthier, which push the traditional carving techniques and materials to the limit; and the powerful photographic work of Barry Pottle and Chris P. Sampson.

The final section, The Next Generation, looks at more traditional craft (mitts, boots) and carving as well as photography and drawings by a younger generation. Barry Pottle's essay points out that although this generation can connect to other artists and ideas through social media without having to leave Labrador, the artists continue to celebrate the Nunatsiavummiut culture and place. The pen-and-ink drawing by Jason Shiwak that depicts a struggle between a shaman and a Christian missionary stands out. Jennie Williams's photographs document a unique Labrador Inuit Old Christmas festivity that marries Moravian and Inuit traditions.

This publication is a welcome documentation of a comprehensive, landmark exhibition and a history of the development of modern and contemporary Nunatsiavummiut art. Interestingly, while this is an "art" publication, Igloliorte's essay reads as an industrial and structural analysis that tracks the path of four generations of Labrador Inuit art, 
from being unacknowledged to becoming accepted in the mainstream art world and markets. A corollary is that the arts and craft sector can be an economic driver for the Nunatsiavummuit as it is elsewhere in Inuit communities further north.

One of the most valuable aspects of the publication revolves around the question of what is "authentic" Inuit art. This issue is raised both by Igloliorte and by Christine Lalonde, a curator at the National Gallery of Canada, in her introduction to the Fire Keepers section. The prints and sculpture produced by Inuit artists at Cape Dorset, Baker Lake, and other co-operatives in the North originally depicted traditional stories and a way of life. The work tended to be idiomatic. Over the years there has been much discussion regarding the role of the market and whether or not Inuit art was more "product" and less "art"; however, the Inuit artists maintained that the traditional stories and way of life had a resonance for them. It was not until the late 1970s/early 1980s that images began to reflect the contemporary situation of Inuit artists. Lalonde points out in her essay that the isolation not only allowed Labrador Inuit artists and craftspersons to develop a unique voice but to challenge and expand on what "authentic" Inuit art can be:

the upside of being unrecognized has been choice - the option to move away or stay in coastal Labrador; the right to depict subject matter that is meaningful to themselves - whether that be photographing a swimming pool in Kuujjuaq or painting a "komatiq" (dog sled) in oils. Again, as Igloliorte has noted, working outside the co-operative system and therefore being less pressured by market expectations, Nunatsiavut artists have used this form of freedom to develop experimental and individual approaches that have been largely unfettered by the discourses of authenticity that have attempted to shape and limit Inuit art in the past. (103) 
It is to the curator's credit that the text does not overwhelm the publication. The writing by all contributors is succinct and useful but allows the artwork to speak for itself.

Charlotte Jones (retired) Grenfell Campus Art Gallery, Memorial University of Newfoundland

Mary Walsh. Crying for the Moon. Toronto: HarperCollins, 2017. ISBN 978-1-44341-036-6

Crying for the Moon (2017) is Mary Walsh's debut novel, published after decades of award-winning work as an actress, comedian, director, producer, and social activist. Both Bildungsroman and murder mystery, it concentrates on Maureen Brennan, a teenager born in St. John's, Newfoundland. Love, physical and emotional abuse, teenage pregnancy, alcoholism, and drugs are all themes explored in the novel. Maureen's struggle to gain emotional strength is in fact intensified by the dysfunctional environment in which she lives, the people who surround her, and the choices she makes.

The main sections of the novel are preceded by a brief prologue set in 1970, where we learn of how Maureen has poisoned the food in the fridge following one of her violent boyfriend Bo's beatings. The prologue then is followed by three parts. Part 1 begins with Maureen's successful attempt to join her religious school's choir so that she can attend Expo 67 in Montreal. The second daughter of a strict, abusive mother and of a distant and often drunk father, she lives at her family home on Princess Street with her parents and disabled sister. Once she reaches Montreal, Maureen visits disreputable pubs with her friend Carleen and ends up pregnant. Back in St. John's, she is sent away 